\title{
CELESTINESCA
}

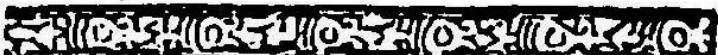

\section{SPANISH URBAN LIFE IN THE LATE FIFTEENTH CENTURY AS SEEN IN CELESTINA}

\author{
John Lihani \\ University of Kentucky
}

Celestina is a long dramatic masterpiece written in the last decade of the fifteenth century by Fernando de Rojas, then a precocious student at the University of Salamanca. It presents one of the most memorable pictures of a Spanish community that can be found anywhere in western literature. We here will consider some of the aspects of Spanish psychology and everyday lifestyles of the people that Rojas presented in this multifaceted, delightful depiction of love, greed, hypocrisy, sex, frustration, and death.

The characters involved are Celestina, the bawd; her two protegées, Elicia and Areúsa; Calisto the handsome lover; and his two servants, Sempronio and Pármeno; and Melibea, the love object, who lives with her parents and a maid. In the first instance we should note that we have a common master-servant relationship which is ubiquitous and in which the servant by virtue of his adherence to the family is considered as part of that family. The master condescendingly of ten refers to his servant with the term "brother," for they may have grown up together, but the servant may never reciprocate the familiar relationship, and must always address his employer as "sir" or "master". In addition to the usual room and board and in recognition for their services, masters commonly gave their employees pieces of clothing, if not money. ${ }^{1}$ The bond between master and servant was one based on economic necessity and on greed, rather than on fondness and altruism. ${ }^{2}$ In their materialistic attitude the servants were motivated by selfish interests and the masters by avarice.

Celestina's profession as a bawd was condemned in the fifteenth century much as it evidently is today. Everyone knew her as the woman of the town, or at least had heard of Celestina and her girls [I, 68]. She 


\section{CELESTIINESCA}

was notorious for having spoiled and recycled many of the virgins in the city. Indeed, Celestina's solitary, half-ruined dwelling located on the outskirts of town, confirms her low social standing and her role as a social outcast. She lived on the edge of the city, where even today European slums are located (just the reverse of American cities); and she lived next to the foul smelling tanneries on a small hill by the river [I, 70].

The role of the upstanding medieval woman in general was rather unique, in that the honor of the family rested on her good reputation. The opinion of women held by men was ambivalent, thereby revealing the transitional nature of the period as it edged from the medieval to the Renaissance forms of thinking. While it is unwise to generalize, the impression that Spanish medieval literature leaves on the reader is that many of the Spanish medieval writers in general, and the didactic ones in particular, looked on woman as a deceitful creature. This was counterbalanced by some narrative poets, e.g., in the Poema de Mio Cid, and later by the Renaissance authors who revered woman's beauty and exalted her virtue. It is noteworthy that both these outlooks are evident in Celestina. The medieval opinion of women is adhered to by the servants. They speak of women's lies, of their deceits, of their being a weapon of the devil, and a destroyer of paradise [I, 47-50]. One of Celestina's protégées (Elicia) bears this out when while being visited by one of her lovers, she hides another one (Crito) in the broom closet, there to wait his turn.

On the other hand, the Renaissance view which is more appreciative of woman is embodied in the master, Calisto. But is Calisto's view of Melibea to be taken as representative? He is a man hopelessly in love, and his senses are grossly distorted. He is in fact a parody of the traditional courtly lover.

Along with the ambivalent attitude toward women, Fernando de Rojas reveals the characters' inclination toward materialism. We have seen that masters of ten gave their servants articles of clothing in return for the services rendered. Celestina, the procuress, is an example of greed personified. The driving force in her life is money. Her various occupations are practiced for financial gain. Each object that she sells, each task she undertakes, is carried out for the purpose of acquiring money. Her trades seem innocuous enough and typical of the day: she is a seamstress, a perfumer, a cosmetician, a beauty consultant, a restorer of maidenheads, a go-between, a doctor and a witch. She gladly acts as 


\section{CELESTINESCA}

Calisto's go-between because she expects to be well rewarded for her efforts if she succeeds in making Melibea accept Calisto. Celestina is continuously thinking of the payment she will receive. In her greed, on a visit to Calisto's house she mutters that she doesn't want to hear what Calisto has to say, but rather she wants him to open up his purse-strings. When she receives a valuable gold chain from him as part payment of her sevices, she is so overwhelmed by her new-found wealth that she cannot fathom the idea of sharing it with Calisto's servants who worked in collusion with her. The chain weighing eleven troy ounces, would have a current value of about $\$ 3,300$. The same greed that controls her also motivates the two accomplices to contest her ownership of, the chain. One of them confronts her by saying, "O avaricious woman, gullet dying of thirst for money! You won't be happy with just a third of our earnings?" [II, 103, my transl.]. Secular greed in different forms, rather than religious charity, is the theme of Rojas' work. Calisto, the lover, while wealthy and avaricious, is also overcome with desire for physical union with Melibea.

Another important aspect of society that is dealt with in Celestina is that of religion and its misuse. At this point, we should recall that this work was probably written by Rojas in 1497 (though published in 1499 or 1500), just five years after the conquest of Granada by the Catholic Kings. At that time the Church began to force the Jews and Moors to convert to catholicism, and to penalize those who did not do so. The Inquisition was a much feared and hated institution which persecuted converts and Christians for heresy. The clergy constituted the politicians of the day, many of whom were morally corrupt. They too sought physical love and money, along with financial power over others. The negative reactions of the Spanish people to the actions of the Church are reflected in a subtle way in Celestina. The first example of anti-religious sentiment is illustrated by Calisto when he heretically proclaims not to be a Christian, but a Melibean--a worshipper of his beloved Melibea [1, 41]. Celestina and her girls take advantage of the corruption of the clergy and even encourage it. An example of this is borne out when Celestina deceitfully tells Sempronio that she is keeping a girl upstairs for one of the friars. Celestina, herself, is a religious hypocrite. Like some other church-goers of the period, she attends church for "appearances," but most importantly she goes there to make her business contacts [I, 71-2]. Celestina is irreverent, and readily corrupts pious women along with her friars [I, 81]. 


\section{CELESTINESCA}

Melibea's cordón, or sash, becomes a further mockery of religion. People of the Middle Ages placed much value on relics. Since Melibea's sash had touched a relic in the Holy Land, its value had increased. Its function, however, in this drama is not for a religious purpose, as an instrument of faith-healing, but rather as a prelude to the illicit relationship of the lovers. The sash in the hands of Calisto increased his desire to possess Melibea, and became a link which tied them together in their search for carnal satisfaction.

What we call witchcraft was at its height in the late Middle Ages. Rather than looking to God to bring about a desirable outcome, witches mysteriously claimed the ability to concoct potions which, through the devil's aid, could put spells on people. Celestina's foremost role is that of a witch, and Rojas goes to great lengths to give an exact description of Celestina's laboratory [I, 73-4], and the ingredients of her potions such as snake oil, bat's blood, hairs of a ram's beard, and the eyes of a wolf stored in the skin of a black cat [I, 142-7].

Superstition, closely related to witcheraft, also plays an important role in medieval social beliefs, and is illustrated in Celestina. On her way to Melibea's house, Celestina doubts whether she is doing the right thing, but convinces herself that indeed she is because she has encountered only good omens: on her way she has met only males (two of them are "Johns" and two are cuckolds); the stones seem to clear the way for her; dogs do not bark at her approach, and she has not seen any blackbird [I, 156-8].

Rojas fills Celestina with colorful descriptions of a medieval town and its activities. We have already noted the neighborhood where the protagonist lived. Its streets are muddy and unsafe at night. The old gobetween always walks in the middle of the road; even though she gets her shoes dirty, because danger lurks in the doorways and around corners (Act XI). During her nocturnal escapades, she takes consolation in her advanced age (between 60 and 72), for she no longer needs to fear rape on the street. ${ }^{3}$

The first signs of the day's activities in the city belong to the early risers who are the wealthy, greedy for temporal wealth; the devout in the temples, the enamored, the farmers, and the shepherds who go to the folds to milk their sheep [II, 121]. The various trades of the townspeople are elaborated, and the following professions are named: blacksmith, carpenter, farrier, boiler maker, cabinet maker, hairdresser, 


\section{CELESTINESCA}

weaver, gardener [II, 121], merchant, physician [I, 65-66], and judges, both honest and corrupt [I, 124-5].

From Fernando de Rojas we also learn of foods typical of Castile. At Celestina's dinner, the main course is white bread, wine from Monviedro, pork shoulder, chicken, and turtledoves [II, 17]. In times of plenty, Celestina kept her wine in pigskins [I, 173-4], but in leaner times, Celestina confesses she had to run to the local tavern six times a day in order to get her cups of wine. Wine holds many virtues for her (Act IX): she claims to use it to keep her warm, to fight bad breath, to put color in her face, to bolster her courage, to cure colds, and even to cure toothaches.

In urban centers like Salamanca, people seemed preoccupied with their personal appearances. This is illustrated in the cosmetics that women used, and which Celestina concocted in her laboratory. These cosmetics were corrosive sublimate, rouge, silver paste, waxes, ointments, polishes, skin lighteners, lotions; and other facial waters. And she slenderised skin with lemon juices [I, 74-6]. Celestina talks about dressing in skirts, and the men speak of wearing swords and cloaks when going out in the streets. The servant Pármeno speaks of his attire as including a helmet, a chest plate, and a sword--the last two tied on with leather thongs, so that they would not fall when he's on the run [I, 88-9].

To entertain themselves, the people would play the guitar, sing songs, tell stories, play cards and chess [I, 116]. Although they do not mention them, we know from other evidence that they also had plays and dances which they could attend. ${ }^{4}$

With regard to music, it appears in Celestina as a type of tranquilizing medicine which soothes the unsettled nerves. For examples, Melibea uses it to ease her lovesick suffering. She asks her father to have a stringed instrument brought to her which she can strum and sing with, so that her sadness can be mitigated by its sweet tones and happy harmony [II, 191]. When Calisto laments his anguished love, he asks one of his servants to bring him a "laúd" (I, 39).

Rojas presented a society in the Spanish urban center that was divided between the "haves" and the "have nots." The servants in Celestina are the representatives of the "have nots." But poverty does not dull their spirit. Though Pármeno hasn't much money, he possesses as much pride and contentment as any man with money. This is illustrated when he confesses: "I would not live happily with wealth, in fact I 


\section{CELESTINESCA}

consider happy poverty a good thing. And I'll tell you something else: those people who have little, are not necessarily poor, but those are the poor ones, who desire a lot" [I, 103, my transl.]. The poor seem to regard the wealthy with some scorn. Celestina expresses it thus: "I'm loved for my person; the wealthy one is loved for his possessions. He never hears the truth, everyone flatters him, and all envy him. You'll hardly find a rich man who will not confess that he would be happier in modest circunstances or in honest poverty. Wealth does not make a man rich; it only makes him worried." She continues, "Wealth has brought death to many. It deprives people of pleasure and of good habits, nothing can be worse. Haven't you heard it said, 'men of wealth went to sleep, and then found their hands empty?' Every rich man has a dozen kids and nephews, who pray nothing else, nor ask anything more than that God take him from this earth..., and that the way to his eternal rest not be too costly for them" [1, 168, my transl.].

Rojas gives us an inkling of what it was like to be old in the latter part of the fifteenth century. There were health and economic problems for the senior citizens in particular. Celestina says this of her experience in old age: "If I could only tell you of its burdens... of its illnesses, of its cold, of its heat, its unhappiness, its heartburn, its sorrow; that wrinkling of the face, that graying of the hair...; that loss of hearing, that loss of eyesight, with eyes staring in the darkness, that sinking of the mouth, that falling out of teeth, that lack of strength, that weakening gait, that slowness in eating? And, oh my, my... if all this is accompanied by poverty, then you'll see all the other troubles fade away" [I, 165-6, my transl.].

Death comes several times in the course of this dramatic work. Calisto's servants kill Celestina during their argument over the gold chain. They want part of the chain, and she refuses to share it with them. In their anger they stab her to death. Then, they in turn are apprehended and summarily executed in the town square. In another part of town, Calisto falls to his death when retreating over the garden wall, after his rendezvous with his sweetheart Melibea. And Melibea commits suicide to rejoin her lover in death. Melibea's mother lies prostrate over her daughter's body in the concluding scene of the play. Desire and greed are the motivating causes for several of the deaths. But those people that remain alive have long ago discovered truths about life and death. As Elicia, one of the paramours, observes, "Although the rich are better prepared to gain everlasting glory than the poor, there's no one who's 


\section{CELESTINESCA}

happy; there's no one who will say 'I have enough;' there's no one who would not change my pleasure for his money." Elicia ruminates, "As long as we have something to eat let's not think about tomorrow. The rich man dies just as the poor; the doctor like the shepherd; the pope like the sexton, and the master like the servant; and the man of high lineage dies like the man of low birth, and you with your job, and I without any, we all die. We can't live forever. So let's enjoy life and have fun, since few people reach old age, and of those who do grow old, none of them dies of hunger. I don't want anymore in this world than the day itself, and its daily bread, and after that, all I want is just a little corner in Paradise [I, 252-3, my transl.]. But these last words reveal that the desire for immortality remained strong in the late medieval mind.

Celestina played one of the most significant roles in the development of the modern drama and of the novel, with its new tripartite episodic construction of prefiguration, activation and recapitulation. ${ }^{5}$ But aside from its literary contribution, its reflection of the psychology and lifestyle of fifteenth century Spain is equally important, for it allows us an insight into the everyday life of those remarkable people that ushered in the modern period. In this great work produced by the literary genius of Fernando de Rojas we are provided with individualized history--history on an individual, personal level. We see here a panoply of urban life in the Middle Ages, with its secular, humanistic orientation as it descended into the modern period. We can thus appreciate the differences and the similarities in urban lifestyles. Indeed, the modern period has retained much of the medieval philosophy of life, and a similar outlook on its pleasures and on its dangers. While it is true that due to the miracles of medicine and technology, more people live longer and better lives today than they did in the Middle Ages, Celestina tends to show that human nature and the secular ways of human beings have continued on a similar course without significant behavioral changes for at least the last 500 years. $^{6}$

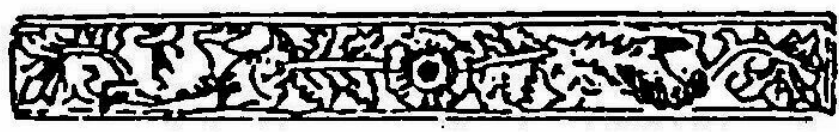




\section{CELESTINESCA}

\section{NOTES}

${ }^{1}$ Fernando de Rojas, La Celestina, ed. by Julio Cejador y Frauca. "Clásicos Castellanos," 2 vols. (Madrid: Espasa-Celpe, 1931): II, 96-97. All subsequent references (volume no. and page) will appear in the text.

${ }^{2}$ Erna Ruth Berndt, Amor, muerte $y$ fortuna en La Celestina (Madrid: Gredos, 1963): 59.

${ }^{3}$ Anne Eesley asks if Celestina may be younger than heretofore believed. See Celestinesca 10, ii (Otoño 1986): 25-30.

${ }^{4}$ John Lihani, Lucas Fernández (New York: Twayne, 1973): 61.

5 John Lihani, "The Intrinsic and Dramatic Values of Celestina's Gold Chain," in S. Bowman, et al., eds., Studies in Honor of Gerald E. Wade (Madrid: Porrúa Turanzas, 1979): 161-165.

${ }^{6} \mathrm{~A}$. version of this study was read first as a paper at the Mountain Interstate Foreign Language Conference held at Wake Forest University, October 11, 1986.
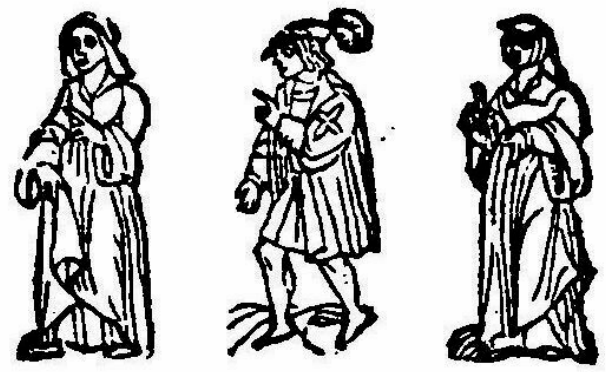

Con licencia imprefra

ENALCALA

En cafa de Iuan de

Villanueua 1569.

\section{IAcolta de Pedro del Bofque li} brero cuAliala.

Portada de la edición de Alcalé, en 1569 